\title{
Anti Q-Fuzzy Group and Its Lower Level Subgroups
}

\author{
Dr.R.Muthuraj \\ Department of Mathematics \\ PSNA CET, Dindigul. - 624622.
}

\author{
P.M.Sitharselvam \\ Department of Mathematics \\ PSNA CET, Dindigul. - 624622.
}

\author{
M.S.Muthuraman \\ Department of Mathematics \\ PSNA CET, Dindigul. - 624622.
}

\begin{abstract}
In this paper, we define the algebraic structures of anti Q-fuzzy subgroup and some related properties are investigated. The purpose of this study is to implement the fuzzy set theory and group theory in anti-Q fuzzy subgroups. Characterizations of lower level subsets of an anti-Q fuzzy subgroup of a group are given.
\end{abstract}

\section{Keywords}

Fuzzy set, Q-fuzzy set, fuzzy subgroup , Q-fuzzy

subgroup, anti-Q fuzzy subgroups.

AMS Subject Classification (2000): 20N25, 03E72, 03F055 , 06F35, 03 G25.

\section{INTRODUCTION}

K.H.Kim introduce the concept of intuitionistic Q-fuzzy semi prime ideals in semi groups and Osman kazanci, sultan yamark and serife yilmaz introduce the concept of intuitionistic Q-fuzzy R-subgroups of near rings and F.H. Rho, K.H.Kim, J.G Lu introduce the concept of intuitionistic Q-fuzzy subalgebras of BCK / BCI- algebras. A.Solairaju and R.Nagarajan introduce and define a new algebraic structure of Q-fuzzy groups. In this paper we define a new algebraic structure of anti Q-fuzzy subgroups and study some their related properties.

\section{Preliminaries}

In this section we site the fundamental definitions that will be used in the sequel.

\subsection{Definition}

Let $\mathrm{S}$ be any non empty set. A fuzzy subset $\mathrm{A}$ of $\mathrm{S}$ is a function $\mathrm{A}: \mathrm{S} \rightarrow[0,1]$.

\subsection{Definition}

Let $\mathrm{G}$ be a group. A fuzzy subset $\mathrm{A}$ of $\mathrm{G}$ is called a fuzzy subgroup if for $\mathrm{x}, \mathrm{y} \in \mathrm{G}$,

(i) $\quad \mathrm{A}(\mathrm{xy}) \geq \min \{\mathrm{A}(\mathrm{x}), \mathrm{A}(\mathrm{y})\}$,

(ii) $\quad \mathrm{A}\left(\mathrm{x}^{-1}\right)=\mathrm{A}(\mathrm{x})$.

\subsection{Definition}

Let $\mathrm{G}$ be a group. A fuzzy subset $\mathrm{A}$ of $\mathrm{G}$ is called an anti fuzzy subgroup if for $x, y \in G$,

(i) $\mathrm{A}(\mathrm{xy}) \leq \max \{\mathrm{A}(\mathrm{x}), \mathrm{A}(\mathrm{y})\}$,

(ii) $\mathrm{A}\left(\mathrm{x}^{-1}\right)=\mathrm{A}(\mathrm{x})$.

\subsection{Definition}

Let $Q$ and $G$ be any two sets. A mapping A : $\mathrm{G} \times \mathrm{Q} \rightarrow[0,1]$ is called a $\mathrm{Q}-$ fuzzy set in $\mathrm{G}$.

\subsection{Definition}

A Q-fuzzy set 'A' is called Q-fuzzy group of a group $\mathrm{G}$ if for $x, y \in G, q \in Q$,

$$
\begin{aligned}
& \text { (i) } \mathrm{A}(\mathrm{xy}, \mathrm{q}) \geq \min \{\mathrm{A}(\mathrm{x}, \mathrm{q}), \mathrm{A}(\mathrm{y}, \mathrm{q})\} \\
& \text { (ii) } \mathrm{A}\left(\mathrm{x}^{-1}, \mathrm{q}\right)=\mathrm{A}(\mathrm{x}, \mathrm{q}) .
\end{aligned}
$$

\subsection{Definition}

A Q-fuzzy set 'A' is called an anti Q-fuzzy group of a group $\mathrm{G}$ if for $\mathrm{x}, \mathrm{y} \in \mathrm{G}, \mathrm{q} \in \mathrm{Q}$,

$$
\begin{aligned}
& \text { (i) } \mathrm{A}(\mathrm{xy}, \mathrm{q}) \leq \max \{\mathrm{A}(\mathrm{x}, \mathrm{q}), \mathrm{A}(\mathrm{y}, \mathrm{q})\} \\
& \text { (ii) } \mathrm{A}\left(\mathrm{x}^{-1}, \mathrm{q}\right)=\mathrm{A}(\mathrm{x}, \mathrm{q}) .
\end{aligned}
$$

\section{Properties of anti Q-fuzzy subgroups}

In this section, we discuss some of the properties of anti Q-fuzzy subgroups. 


\subsection{Theorem}

Let 'A' be an anti Q-fuzzy subgroup of a group $\mathrm{G}$ then

(i) $\quad \mathrm{A}(\mathrm{x}, \mathrm{q}) \geq \mathrm{A}(\mathrm{e}, \mathrm{q})$ for all $\mathrm{x} \in \mathrm{G}, \mathrm{q} \in \mathrm{Q}$ and e is the identity element of $\mathrm{G}$.

(ii) The subset $\mathrm{H}=\{\mathrm{x} \in \mathrm{G} / \mathrm{A}(\mathrm{x}, \mathrm{q})=\mathrm{A}(\mathrm{e}, \mathrm{q})\}$ is a subgroup of G.

Proof

(i) Let $\mathrm{x} \in \mathrm{G}$ and $\mathrm{q} \in \mathrm{Q}$.

$$
\begin{aligned}
& A(x, q) \quad \max \{A(x, q), A(x, q)\} \\
&=\max \left\{A(x, q), A\left(x^{-1}, q\right)\right\} \\
& \geq A\left(x^{-1}, q\right) \\
&=A(e, q) . \\
& A(x, q) \geq A(e, q) .
\end{aligned}
$$

(ii) Let $\mathrm{H}=\{\mathrm{x} \in \mathrm{G} / \mathrm{A}(\mathrm{x}, \mathrm{q})=\mathrm{A}(\mathrm{e}, \mathrm{q})\}$.

Clearly $\mathrm{H}$ is non-empty as $e \in H$. Let $x, y \in H$.

Then, $A(x, q)=A(y, q)=A(e, q)$.

$$
\begin{aligned}
\mathrm{A}\left(\mathrm{xy}^{-1}, \mathrm{q}\right) & \leq \max \left\{\mathrm{A}(\mathrm{x}, \mathrm{q}), \mathrm{A}\left(\mathrm{y}^{-1}, \mathrm{q}\right)\right\} \\
& =\max \{\mathrm{A}(\mathrm{x}, \mathrm{q}), \mathrm{A}(\mathrm{y}, \mathrm{q})\} \\
& =\max \{\mathrm{A}(\mathrm{e}, \mathrm{q}), \mathrm{A}(\mathrm{e}, \mathrm{q})\} \\
& =\mathrm{A}(\mathrm{e}, \mathrm{q}) .
\end{aligned}
$$

That is, $\mathrm{A}\left(\mathrm{xy}^{-1}, \mathrm{q}\right) \leq \mathrm{A}(\mathrm{e}, \mathrm{q})$ and obviously

$$
A\left(x y^{-1}, q\right) \geq A(e, q) \text {. }
$$

Hence, $A\left(x y^{-1}, q\right)=A(e, q)$ and $x y^{-1} \in H$.

Clearly, $\mathrm{H}$ is a subgroup of $\mathrm{G}$.

\subsection{Theorem}

If ' $A$ ' is a Q-fuzzy subgroup of $\mathrm{G}$, iff $\mathrm{A}^{\mathrm{C}}$ is an anti Qfuzzy subgroup of $\mathrm{G}$.

\section{Proof}

Suppose A is a Q-fuzzy subgroup of G. Then for all $\mathrm{x}, \mathrm{y}$ $\in \mathrm{G}$ and $\mathrm{q} \in \mathrm{Q}$,

$$
A(x y, q) \geq \min \{A(x, q), A(y, q)\}
$$

$$
\begin{aligned}
& \Leftrightarrow 1-\mathrm{A}^{\mathrm{c}}(\mathrm{xy}, \mathrm{q}) \geq \min \left\{\left(1-\mathrm{A}^{\mathrm{c}}(\mathrm{x}, \mathrm{q})\right),\left(1-\mathrm{A}^{\mathrm{c}}(\mathrm{y}, \mathrm{q})\right)\right\} \\
& \Leftrightarrow \mathrm{A}^{\mathrm{c}}(\mathrm{xy}, \mathrm{q}) \leq 1-\min \left\{\left(1-\mathrm{A}^{\mathrm{c}}(\mathrm{x}, \mathrm{q})\right),\left(1-\mathrm{A}^{\mathrm{c}}(\mathrm{y}, \mathrm{q})\right)\right\} \\
& \Leftrightarrow \mathrm{A}^{\mathrm{c}}(\mathrm{xy}, \mathrm{q}) \leq \max \left\{\mathrm{A}^{\mathrm{c}}(\mathrm{x}, \mathrm{q}), \mathrm{A}^{\mathrm{c}}(\mathrm{y}, \mathrm{q})\right\} .
\end{aligned}
$$

We have, $A(x, q)=A\left(x^{-1}, q\right)$ for all $x$ in $G$ and $q \in Q$,

$$
\Leftrightarrow 1-\mathrm{A}^{\mathrm{c}}(\mathrm{x}, \mathrm{q}) \quad=1-\mathrm{A}^{\mathrm{c}}\left(\mathrm{x}^{-1}, \mathrm{q}\right) .
$$

Therefore, $\quad \mathrm{A}^{\mathrm{c}}(\mathrm{x}, \mathrm{q})=\mathrm{A}^{\mathrm{c}}\left(\mathrm{x}^{-1}, \mathrm{q}\right)$.

Hence $\mathrm{A}^{\mathrm{c}}$ is an anti Q-fuzzy subgroup of $\mathrm{G}$.

\subsection{Theorem}

Let A be any anti Q-fuzzy subgroup of a group $\mathrm{G}$ with identity e. Then $\mathrm{A}\left(\mathrm{xy}^{-1}, \mathrm{q}\right)=\mathrm{A}(\mathrm{e}, \mathrm{q}) \Rightarrow \mathrm{A}(\mathrm{x}, \mathrm{q})=\mathrm{A}(\mathrm{y}, \mathrm{q})$ for all $\mathrm{x}, \mathrm{y}$ in $\mathrm{G}$ and $\mathrm{q} \in \mathrm{Q}$.

Proof

Given $\mathrm{A}$ is an anti Q-fuzzy subgroup of $\mathrm{G}$ and $A\left(x y^{-1}, q\right)=A(e, q)$.

Then for all $x, y$ in $G$ and $q \in Q$,

$$
\begin{aligned}
\mathrm{A}(\mathrm{x}, \mathrm{q}) & =\mathrm{A}\left(\mathrm{x}\left(\mathrm{y}^{-1} \mathrm{y}\right), \mathrm{q}\right) \\
& =\mathrm{A}\left(\left(\mathrm{xy}^{-1}\right) \mathrm{y}, \mathrm{q}\right) \\
& \leq \max \left\{\mathrm{A}\left(\mathrm{xy}^{-1}, \mathrm{q}\right), \mathrm{A}(\mathrm{y}, \mathrm{q})\right\} \\
& =\max \{\mathrm{A}(\mathrm{e}, \mathrm{q}), \mathrm{A}(\mathrm{y}, \mathrm{q})\} \\
& =\mathrm{A}(\mathrm{y}, \mathrm{q}) .
\end{aligned}
$$

That is, $\quad \mathrm{A}(\mathrm{x}, \mathrm{q}) \leq \mathrm{A}(\mathrm{y}, \mathrm{q})$.

Now, $\mathrm{A}(\mathrm{y}, \mathrm{q})=\mathrm{A}\left(\mathrm{y}^{-1}, \mathrm{q}\right)$, since $\mathrm{A}$ is an anti Q-fuzzy subgroup of $\mathrm{G}$.

$$
\begin{aligned}
& =\mathrm{A}\left(\mathrm{ey}^{-1}, \mathrm{q}\right) \\
& =\mathrm{A}\left(\left(\mathrm{x}^{-1} \mathrm{x}\right) \mathrm{y}^{-1}, \mathrm{q}\right) \\
& =\mathrm{A}\left(\mathrm{x}^{-1}\left(\mathrm{xy}^{-1}\right), \mathrm{q}\right)
\end{aligned}
$$




\author{
$\leq \max \left\{\mathrm{A}\left(\mathrm{x}^{-1}, \mathrm{q}\right), \mathrm{A}\left(\mathrm{x} \mathrm{y}^{-1}, \mathrm{q}\right)\right\}$ \\ $=\max \{\mathrm{A}(\mathrm{x}, \mathrm{q}), \mathrm{A}(\mathrm{e}, \mathrm{q})\}$ \\ $=\mathrm{A}(\mathrm{x}, \mathrm{q})$. \\ (i.e.) $\mathrm{A}(\mathrm{y}, \mathrm{q}) \leq \mathrm{A}(\mathrm{x}, \mathrm{q})$. \\ Hence, $A(x, q)=A(y, q)$.
}

\subsection{Theorem}

A is an anti Q-fuzzy subgroup of a group G if and only

if $\mathrm{A}\left(\mathrm{x} \mathrm{y}^{-1}, \mathrm{q}\right) \leq \max \{\mathrm{A}(\mathrm{x}, \mathrm{q}), \mathrm{A}(\mathrm{y}, \mathrm{q})\}$, for all $\mathrm{x}, \mathrm{y}$ in $\mathrm{G}$ and $\mathrm{q} \in \mathrm{Q}$.

Proof

Let A be an anti Q-fuzzy subgroup of a group G. Then for all $\mathrm{x}, \mathrm{y}$ in $\mathrm{G}$ and $\mathrm{q} \in \mathrm{Q}$,

$$
\mathrm{A}(\mathrm{xy}, \mathrm{q}) \leq \max \{\mathrm{A}(\mathrm{x}, \mathrm{q}), \mathrm{A}(\mathrm{y}, \mathrm{q})\}
$$

and

$$
A(x, q)=A\left(x^{-1}, q\right)
$$

Now, $\quad \mathrm{A}\left(\mathrm{x} \mathrm{y}^{-1}, \mathrm{q}\right) \leq \max \left\{\mathrm{A}(\mathrm{x}, \mathrm{q}), \mathrm{A}\left(\mathrm{y}^{-1}, \mathrm{q}\right)\right\}$.

$$
=\max \{\mathrm{A}(\mathrm{x}, \mathrm{q}), \mathrm{A}(\mathrm{y}, \mathrm{q})\}
$$

$\Leftrightarrow \mathrm{A}\left(\mathrm{xy}^{-1}, \mathrm{q}\right) \leq \max \{\mathrm{A}(\mathrm{x}, \mathrm{q}), \mathrm{A}(\mathrm{y}, \mathrm{q})\}$.

4. Properties of Lower level subsets of an anti Q-fuzzy subgroup

In this section, we introduce the concept of lower level subset of an anti Q-fuzzy subgroup and discuss some of its properties.

\subsection{Definition}

Let A be an anti Q-fuzzy group of a group G. For any $\mathrm{t}$ $\in[0,1]$, we define the lower level subset of $\mathrm{A}$ is the set, $L(A ; t)=\{x \in G / A(x, q) \leq t\}$.

\subsection{Theorem}

Let A be an anti Q-fuzzy subgroup of a group G. Then for $\mathrm{t} \in[0,1]$ such that $\mathrm{t} \geq \mathrm{A}(\mathrm{e}, \mathrm{q}), \mathrm{L}(\mathrm{A} ; \mathrm{t})$ is a subgroup of $\mathrm{G}$.

\section{Proof}

For all $\mathrm{x}, \mathrm{y} \in \mathrm{L}(\mathrm{A} ; \mathrm{t})$, we have,

$$
\mathrm{A}(\mathrm{x}, \mathrm{q}) \leq \mathrm{t} ; \mathrm{A}(\mathrm{y}, \mathrm{q}) \leq \mathrm{t} .
$$

$$
\text { Now, } \begin{aligned}
\mathrm{A}\left(\mathrm{xy}^{-1}, \mathrm{q}\right) & \leq \max \{\mathrm{A}(\mathrm{x}, \mathrm{q}), \mathrm{A}(\mathrm{y}, \mathrm{q})\} . \\
\mathrm{A}\left(\mathrm{xy}^{-1}, \mathrm{q}\right) & \leq \max \{\mathrm{t}, \mathrm{t}\} . \\
\mathrm{A}\left(\mathrm{xy}^{-1}, \mathrm{q}\right) & \leq \mathrm{t} . \\
\mathrm{x} \mathrm{y}^{-1} & \in \mathrm{L}(\mathrm{A} ; \mathrm{t}) .
\end{aligned}
$$

Hence $L(A ; t)$ is a subgroup of $G$.

\subsection{Theorem}

Let $\mathrm{G}$ be a group and A be a Q-fuzzy subset of G such that $\mathrm{L}(\mathrm{A} ; \mathrm{t})$ is a subgroup of $\mathrm{G}$. For $\mathrm{t} \in[0,1]$ such that $\mathrm{t} \geq \mathrm{A}(\mathrm{e}), \mathrm{A}$ is an anti Q-fuzzy subgroup of $\mathrm{G}$.

Proof

$$
\text { Let } \mathrm{x}, \mathrm{y} \text { in } \mathrm{G} \text { and } \mathrm{A}(\mathrm{x})=\mathrm{t}_{1} \text { and } \mathrm{A}(\mathrm{y})=\mathrm{t}_{2} \text {. }
$$

Suppose $t_{1}<t_{2}$, then $x, y \in L\left(A ; t_{2}\right)$.

As $\mathrm{L}\left(\mathrm{A} ; \mathrm{t}_{2}\right)$ is a subgroup of $\mathrm{G}, \quad \mathrm{x}^{-1} \in \mathrm{L}\left(\mathrm{A} ; \mathrm{t}_{2}\right)$.

Hence,

$$
\begin{aligned}
\mathrm{A}\left(\mathrm{xy}^{-1}, \mathrm{q}\right) & \leq \mathrm{t}_{2}=\max \left\{\mathrm{t}_{1}, \mathrm{t}_{2}\right\} \\
& \leq \max \{\mathrm{A}(\mathrm{x}, \mathrm{q}), \mathrm{A}(\mathrm{y}, \mathrm{q})\}
\end{aligned}
$$

That is, $\mathrm{A}\left(\mathrm{xy}^{-1}, \mathrm{q}\right) \leq \max \{\mathrm{A}(\mathrm{x}, \mathrm{q}), \mathrm{A}(\mathrm{y}, \mathrm{q})\}$.

Hence A is an anti Q-fuzzy subgroup of G. 


\subsection{Definition}

Let A be an anti Q-fuzzy subgroup of a group G. The subgroups $\mathrm{L}(\mathrm{A} ; \mathrm{t})$ for $\mathrm{t} \in[0,1]$ and $\mathrm{t} \geq \mathrm{A}(\mathrm{e})$, are called lower level subgroups of A.

\subsection{Theorem}

Let A be an anti Q-fuzzy subgroup of a group G. If two lower level subgroups $\mathrm{L}\left(\mathrm{A} ; \mathrm{t}_{1}\right), \mathrm{L}\left(\mathrm{A} ; \mathrm{t}_{2}\right)$, for, $\mathrm{t}_{1}, \mathrm{t}_{2} \in[0,1]$ and $t_{1}, t_{2} \geq A(e, q)$ with $t_{1}<t_{2}$ of $A$ are equal then there is no $x$ in $\mathrm{G}$ such that $\mathrm{t}_{1}<\mathrm{A}(\mathrm{x}, \mathrm{q}) \leq \mathrm{t}_{2}$.

Proof

$$
\text { Let } \mathrm{L}\left(\mathrm{A} ; \mathrm{t}_{1}\right)=\mathrm{L}\left(\mathrm{A} ; \mathrm{t}_{2}\right) \text {. }
$$

Suppose there exists a $x \in G$ such that $t_{1}<A(x, q) \leq t_{2}$ then $\mathrm{L}\left(\mathrm{A} ; \mathrm{t}_{1}\right) \subseteq \mathrm{L}\left(\mathrm{A} ; \mathrm{t}_{2}\right)$

Then $\mathrm{x} \in \mathrm{L}\left(\mathrm{A} ; \mathrm{t}_{2}\right)$, but $\mathrm{x} \notin \mathrm{L}\left(\mathrm{A} ; \mathrm{t}_{1}\right)$, which contradicts the assumption that, $\mathrm{L}\left(\mathrm{A} ; \mathrm{t}_{1}\right)=\mathrm{L}\left(\mathrm{A} ; \mathrm{t}_{2}\right)$. Hence there is no $\mathrm{x}$ in $\mathrm{G}$ such that $\mathrm{t}_{1}<\mathrm{A}(\mathrm{x}, \mathrm{q}) \leq \mathrm{t}_{2}$.

Conversely, suppose that there is no $x$ in $G$ such that $\mathrm{t}_{1}<\mathrm{A}(\mathrm{x}, \mathrm{q}) \leq \mathrm{t}_{2}$

Then, by definition, $\mathrm{L}\left(\mathrm{A} ; \mathrm{t}_{1}\right) \subseteq \mathrm{L}\left(\mathrm{A} ; \mathrm{t}_{2}\right)$.

Let $\mathrm{x} \in \mathrm{L}\left(\mathrm{A} ; \mathrm{t}_{2}\right)$ and there is no $\mathrm{x}$ in $\mathrm{G}$ such that $\mathrm{t}_{1}<\mathrm{A}(\mathrm{x}, \mathrm{q}) \leq \mathrm{t}_{2}$.

Hence $\mathrm{x} \in \mathrm{L}\left(\mathrm{A} ; \mathrm{t}_{1}\right)$ and $\mathrm{L}\left(\mathrm{A} ; \mathrm{t}_{2}\right) \subseteq \mathrm{L}\left(\mathrm{A} ; \mathrm{t}_{1}\right)$.

Hence $L\left(A ; t_{1}\right)=L\left(A ; t_{2}\right)$.

\subsection{Theorem}

A Q-fuzzy subset A of G is an anti Q-fuzzy subgroup of a group $G$ if and only if the lower level subsets $L(A ; t)$, $\mathrm{t} \in$ Image A, are subgroups of $\mathrm{G}$.

Proof It is clear.

\subsection{Theorem}

Any subgroup $\mathrm{H}$ of a group $\mathrm{G}$ can be realized as a lower level subgroup of some anti Q-fuzzy subgroup of G.

Proof:

Let $\mathrm{A}$ be a Q-fuzzy subset and $\mathrm{x} \in \mathrm{G}$ and $\mathrm{q} \in \mathrm{Q}$.

Define,

$$
A(x, q)= \begin{cases}0 & \text { if } x \in H \\ t & \text { if } x \notin H, \text { where } t \in(0,1] .\end{cases}
$$

We shall prove that A is an anti Q-fuzzy subgroup of G.

Let $\mathrm{x}, \mathrm{y} \in \mathrm{G}$ and $\mathrm{q} \in \mathrm{Q}$.

i. Suppose $\mathrm{x}, \mathrm{y} \in \mathrm{H}$, then $\mathrm{xy} \in \mathrm{H}$ and $x y^{-1} \in \mathrm{H}$.

$$
\mathrm{A}(\mathrm{x}, \mathrm{q})=0, \mathrm{~A}(\mathrm{y}, \mathrm{q})=0, \mathrm{~A} \text { and } \mathrm{A}\left(\mathrm{xy}^{-1}, \mathrm{q}\right)=0
$$

Hence $\mathrm{A}\left(\mathrm{xy}^{-1}, \mathrm{q}\right) \leq \max \{\mathrm{A}(\mathrm{x}, \mathrm{q}), \mathrm{A}(\mathrm{y}, \mathrm{q})\}$.

ii. Suppose $\mathrm{x} \in \mathrm{H}$ and $\mathrm{y} \notin \mathrm{H}$, then $\mathrm{xy} \notin \mathrm{H}$ and $x \mathrm{y}^{-1} \notin \mathrm{H}$.

$A(x, q)=0, A(y, q)=t$ and $A\left(x y^{-1}, q\right)=t$.

Hence $\mathrm{A}\left(\mathrm{xy}^{-1}, \mathrm{q}\right) \leq \max \{\mathrm{A}(\mathrm{x}, \mathrm{q}), \mathrm{A}(\mathrm{y}, \mathrm{q})\}$.

iii. Suppose $\mathrm{x}, \mathrm{y} \notin \mathrm{H}$, then $\mathrm{xy}^{-1} \in \mathrm{H}$ or $\mathrm{xy}^{-1} \notin \mathrm{H}$.

$$
\mathrm{A}(\mathrm{x}, \mathrm{q})=\mathrm{t}, \mathrm{A}(\mathrm{y}, \mathrm{q})=\mathrm{t} \text { and } \mathrm{A}\left(\mathrm{xy}^{-1}, \mathrm{q}\right)=0 \text { or } \mathrm{t}
$$

Hence $\mathrm{A}\left(\mathrm{xy}^{-1}, \mathrm{q}\right) \leq \max \{\mathrm{A}(\mathrm{x}, \mathrm{q}), \mathrm{A}(\mathrm{y}, \mathrm{q})\}$.

Thus in all cases, A is an anti Q-fuzzy subgroup of G.

For this anti fuzzy subgroup, $\mathrm{L}(\mathrm{A} ; \mathrm{t})=\mathrm{H}$.

\section{Remark}

As a consequence of the Theorem 4.3, the lower level subgroups of an anti Q-fuzzy subgroup A of a group G form a chain. Since 
$\mathrm{A}(\mathrm{e}, \mathrm{q}) \leq \mathrm{A}(\mathrm{x}, \mathrm{q})$ for all $\mathrm{x}$ in $\mathrm{G}$ and $\mathrm{q} \in \mathrm{Q}$, therefore $\mathrm{L}\left(\mathrm{A} ; \mathrm{t}_{0}\right)$ , where $\mathrm{A}(\mathrm{e}, \mathrm{q})=\mathrm{t}_{0}$ is the smallest and we have the chain :

$\{\mathrm{e}\} \subset \mathrm{L}\left(\mathrm{A} ; \mathrm{t}_{0}\right) \subset \mathrm{L}\left(\mathrm{A} ; \mathrm{t}_{1}\right) \subset \mathrm{L}\left(\mathrm{A} ; \mathrm{t}_{2}\right) \subset \ldots \subset \mathrm{L}\left(\mathrm{A} ; \mathrm{t}_{\mathrm{n}}\right)=\mathrm{G}$, where $\quad \mathrm{t}_{0}<\mathrm{t}_{1}<\mathrm{t}_{2}<\ldots . .<\mathrm{t}_{\mathrm{n}}$

\section{References}

[1] K.H.Kim, Y.B.Yun, on fuzzy R- subgroups of near rings, J.fuzzy math 8 (3) (2000) 549-558.

[2] K.H.Kim, Y.B.Jun. Normal fuzzy R- subgroups in near rings, Fuzzy sets systems 121 (2001) 341-345.

[3] K.H.Kim, on intuitionistic Q- fuzzy semi prime ideals in semi groups, Advances in fuzzy mathematics, 1 (1) (2006) 15-21.
[4] Osman kazanci, sultan yamark and serife yilmaz "On intuitionistic Q- fuzzy R-subgroups of near rings" International mathematical forum, 2, 2007 no. 59, 2899-2910.

[5] N.Palaniappan , R.Muthuraj , Anti fuzzy group and Lower level subgroups, Antartica J.Math., 1 (1) (2004) , 71-76.

[6] A.Rosenfeld, fuzzy groups, J. math. Anal.Appl. 35 (1971), 512-517.

[7] A.Solairaju and R.Nagarajan “ Q- fuzzy left R- subgroups of near rings w.r.t T- norms", Antarctica journal of mathematics.5, (1-2), 2008.

[8] A.Solairaju and R.Nagarajan, A New Structure and Construction of Q-Fuzzy Groups, Advances in fuzzy mathematics, Volume 4 , Number 1 (2009) pp.23-29. 